\title{
Psychological Reactance Management via Nonlinear Dynamic Motivation in Classroom and Telecollaborative Second Language Learning Contexts
}

\author{
Akbar Bahari \\ University of Qom, Iran \\ Baharizkbar2020@gmail.com
}

\begin{abstract}
Drawing on dynamic systems theory, FonF practice model and psychological reactance theory, the present study proposed reinforcing nonlinear dynamic motivation (NDM) as a facilitator to manage psychological reactance in three forms of incivility, dissent, and resistance among classroom and telecollaborative second language (L2) learners and teachers. Given the dynamicity and nonlinearity of motivation which differ from language to language and learner to learner, the current study aimed at exploring the possible impact of NDM on psychological reactance as a source of different behavioral problems in learning context. To find out whether NDM has the potential to prevent/minimize psychological reactance with regard to learner-teacher anxiety, frustration, and self-doubt a mixed methods study was conducted among 275 EFL learners. Implications of the study include the significance of NDM-oriented strategies at managing reactance in three forms of resistance, incivility, and dissent. Methodological triangulation of data from different participants and different contexts with regards to oppositional behavior indicated significant relationship between NDM and managing reactance among language teachers as well as language learners.
\end{abstract}

Key words: telecollaboration; nonlinear dynamic motivation (NDM); reactance theory (RT); dynamic systems theory (DST); second language (L2)

Received 14 December 2018/Accepted 5 March 2019 @jEHCP All rights reserved

\section{Introduction}

Psychological reactance theory (RT) argues that taking an oppositional behavior is a common response in human behavior (Brehm, 1996). However most of the studies on learning have attributed psychological reactance to the learner under labels such as 'uncivil behavior' (Achacoso, 2002; Ciani, Summers, \& Easter, 2008; Chowning \& Campbell, 2009; Greenberger, 
Lessard, Chen, \& Farruggia; Lippmann, Bulanda, \& Wagenaar, 2009; Lessard, Chen, \& Farruggia, 2008; Nutt, 2013) or uncivil classroom (Bjorklund \& Rehling, 2009; Clark \& Springer, 2007; Cortina, Magley, Williams, \& Langhout, 2001; Feldmann, 2001). This is mostly done without considering teacher in sharing the blame for non-positive behaviors (e.g. uncivil, dissentive, and resistant behavior in the classroom). This study aims at proving this established trend which is clearly against the basic principle of RT, wrong. Accordingly, teacher along with learner are deemed as the cause of reactance which is expressed in three forms of behavior namely incivility, dissent, and resistance by both sides in learning contexts (i.e. facet-to-face or telecollaborative). It is worth mentioning that it is totally wrong to confuse the reactance situation with anti-ought-to-self concerning $L 2$ motivation. While, the former is a psychological state of mind which might lead to a variety of behavioral expressions including incivility, dissent, and resistance (which are examined in the present study), the latter refers to a type of self, which negatively motivates the learner to proceed with L2 learning. To find out the effectiveness of nonlinear dynamic motivation as a tool to prevent/minimize reactance (i.e. oppositional behavior) among language teachers/learners, a mixed methods approach was conducted to triangulate opposite data sources (i.e. teachers and learners) and to provide a better understanding of oppositional behaviors on both sides of the isle in a context where NDM is catered for. Given the nonlinearity and dynamicity of motivational factors (Bahari, 2019; Dornyei \& Ryan, 2015), which differ from language to language and learner to learner (Bahari, 2018a), the present study tried to test the potential behind NDM as a facilitator to manage psychological reactance in a model as displayed in Fig. 1. 


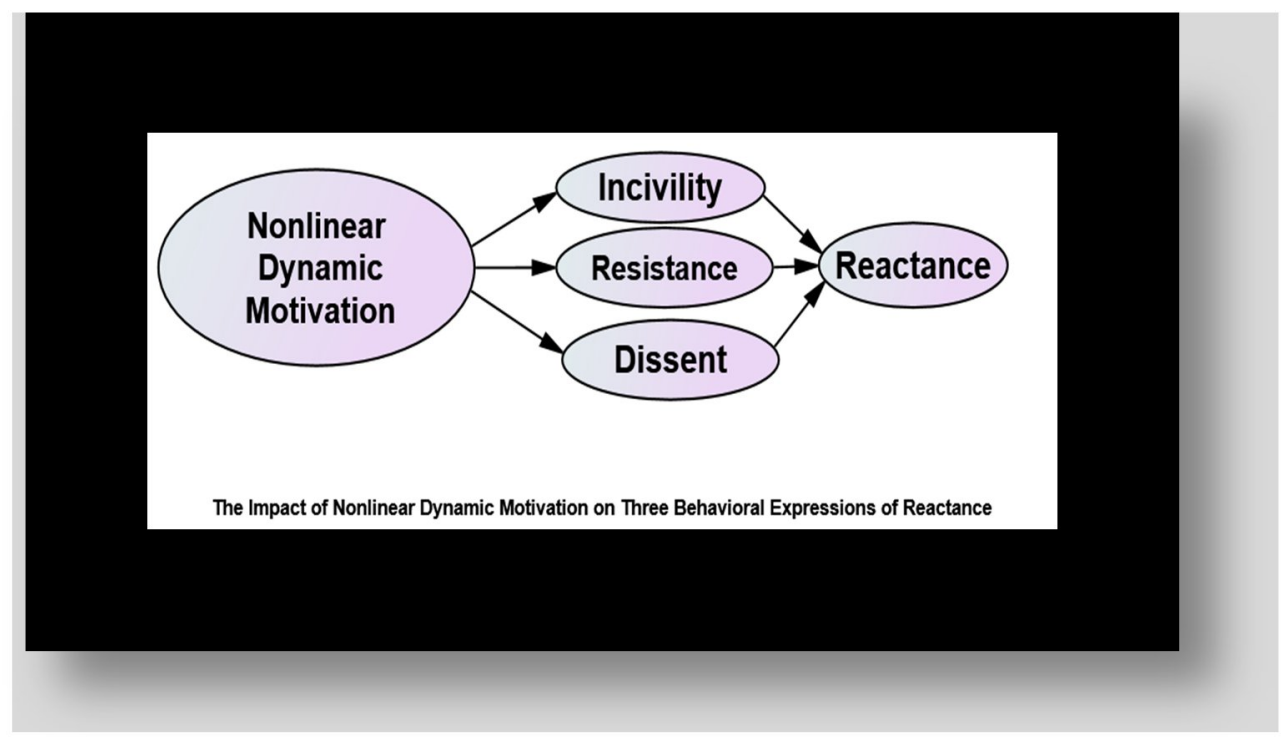

Figure 1 The Impact of Nonlinear Dynamic Motivation on Three Behavioral Expressions of Reactance.

RT and NDM

The basic principle of psychological RT is that oppositional behavior is a common response in human behavior (Brehm, 1996) which is applied to situations where individual autonomy or freedom is restrained by some mechanisms. Given the second language (L2) teaching-learning contexts, the question then arises, "Is there any significant relationship between this psychological state of mind/behavior and nonlinear dynamic motivation in 12 teaching-learning?" imagine a teacher taking demotivating measures by imposing a static and unilateral motivational impetus instead of catering for dynamic and nonlinear motivational needs of the $\mathbf{L}$ learners. How likely is this teacher to face oppositional behavior by those who were not motivated by the single motivational impetus? Addressing one motivational factor among a dynamic group of learners might not lead to unlocking the motivational potential behind every learner. Now the next question arises, can this teacher prevent incivility, minimize resistance, and manage dissent as different expressions of reactance while taking unilateral motivational measures in L2 teaching-learning contexts? The present study is an attempt to find an answer to these questions by exploring the connections between RT and NDM. Restricting learners' pedagogical preferences by ignoring their motivational factors is an example of restricting 
freedom/autonomy in $\mathrm{L} 2$ teaching-learning contexts which increases the chances of reactance (Bahari, 2018c; Jost, Banaji, \& Nosek, 2004). Accordingly, adopting test-oriented instruction, threatening policies, reactance-inducing statements can increase the chances of oppositional behavior among learning-teaching group (Bahari, 2018b). Given the fact that restrictive measures are met with backlash (Kay et al., 2009; Laurin, Kay, Proudfoot, \& Fitzsimons, 2013; Wortman \& Brehm, 1975), they need to be avoided in keeping with internalized concepts of self and identity (Ushioda \& Dornyei, 2017) to facilitate reactance management.

\section{Dynamic Systems Theory (DST) and NDM}

The reported deficiency of linear patterns in explaining and predicting the possible relationships in learning-teaching elements within the second language acquisition studies, served as the rationale to conceptualize non-linear dynamic motivation as a facilitator to manage reactance in keeping with DST (Bot, \& Larsen Freeman, 2011; Bot, Lowie, \& Verspoor, 2007; Dornyei, 2014, 2015; Fusella, 2013; Hiver, 2015; Kikuchi, 2015; Larsen-Freeman \& Cameron, 2008; Maclntyre \& Legatto, 2011). DST considers the elements of the system as a whole and accordingly proposes a nonlinear and dynamic process of organization for internal and external stimuli at work with the system (Henry, Dornyei, \& Daydenko, 2015; Jiang \& Dewaele, 2015). The previous studies have approached $L 2$ teaching-learning motivation with respect to strategies (Griffiths, 2013; Dornyei \& Ryan, 2015; Quoidbach, Mikolajczak, \& Gross, 2015; Oxford, 2017; Schunk \& Zimmerman, 2012) or as a static factor (Moskovsky, Racheva, Assulaimani, \& Harkins, 2016) or as a learner-context interaction subject (Thompson \& Vasquez, 2015; Thompson \& ErdilMoody, 2016). Some studies have introduced influential factors (Lyubomirsky \& Layous, 2013; Sheldon, Boehm, \& Lyubomirsky, 2013; Rusk \& Waters, 2015). However, the present study drawing on DST proposes reinforcing NDM as a psychological management tool to facilitate reactance management and convert the routine and static learning environment into a motivating environment where teacher's and learner's NDM is catered for. 
Telecollaboration and NDM

The significance of motivation and motivation-related concepts in telecollaborative $L 2$ teachinglearning has been analyzed by different studies from a variety of vantage points (Bahari, 2018a; Fong, Lin, \& Engle, 2016; Freiermuth \& Huang, 2012; Garton, Haythornthwaite, \& Wellman, 1997; Jarrell \& Freiermuth, 2005; Klimanova \& Dembovskaya, 2013; Kramsch, A'Ness, \& Lam, 2000; Meunier, 1998; Warschauer, Turbee, \& Roberts, 1996) according to which it can be argued that telecollaboration provides a motivating L2 teaching-learning context and accordingy motivational factors provide intrinsic or extrinsic energy to ensure a consistent motivating dynamic telecollaboration.

\section{The Present Study}

Given the fact that restricting behavioral options can lead to preference for the restricted action (Laurin et al., 2013) and the fact that ignoring motivation or demotivation can negatively influence L2 teaching-learning (Chang, 2010; Dornyei \& Ryan, 2015; Kikuchi, 2009; Kim, 2009; Oxford, 2017; Quoidbach, Mikolajczak, \& Gross, 2015; Trang \& Baldauf, 2007) the present study explored the impact of NDM in managing psychological reactance in three forms of incivility, resistance, and dissent. Given the significant relationship between NDM at individual level and creating a learner-friendly environment as reported by Bahari (2018d), the present study examined the potential behind NDM as a facilitator to deal with the challenges of reactance in L2 teaching context. A mixed methods approach was adopted to explore the possible relationship between NDM and $\mathrm{L} 2$ learner-teacher attitudes towards incivility prevention, resistance minimizing, and dissent management with a focus on three aspects: learner-teacher anxiety, frustration, and self-doubt. In keeping with the framework of the L2 MSS (Dörnyei, Csizer, \& Nemeth, 2006; Dornyei, 2009) and the psychological reactance theory (Thompson \& Vasquez, 2015),different data collection strands were used to collect the required data for the following questions in classroom and telecollaborative environments: 
RQ 1: Is there a relationship between NDM and managing learner-teacher incivility (as a form of psychological reactance)?

RQ2: Is there a relationship between NDM and managing learner-teacher resistance (as a form of psychological reactance)?

RQ3: Is there a relationship between NDM and managing learner-teacher dissent (as a form of psychological reactance)?

RQ4:What type of relationship can be seen between classroom and online participants' responses about reactance management by NDM?

RQ5: Is there a consensus among teachers and learners in classroom and online environments concerning the efficiency of NDM as a facilitator to prevent incivility, minimize resistance, and manage dissent?

\section{Method}

Setting and participants

To facilitate qualitative and quantitative analyses the participants $(N=275)$ who were either teachers ( $N=42)$ or learners ( $N=233$ ) were divided into four groups: classroom teachers ( $N=34 ; 55 \%$ female, $45 \%$ male), online teachers ( $N=8 ; 60 \%$ female, $40 \%$ male), classroom learners ( $N=168 ; 63 \%$ female, $37 \%$ male), and online learners ( $N=65 ; 71 \%$ female, $29 \%$ male). The classroom participants were EFL learners studying English at a private language institute in Tehran, Iran. The average age ranged between 15and 45. To ensure ethical principles the permission to cooperate in the study was obtained from the learners via the management and they were assured about the confidentiality and anonymity of the collected data and its sources. Intact group design was the adopted design of the study, because of the size of the sample, which made it impossible to run a random sampling to ensure generalizability. 


\section{Data sources}

The required data for the first 3 research questions were gathered by administering authormade NDM-oriented reactance management questionnaires for $\mathrm{L} 2$ teacher-learner (see Appendix A). Using the same statements to elicit teacher-learner attitudes on reactance management via NDM the questionnaire was distributed among teachers as well as learners to receive their opinions on the same issue. To collect the required data for the fourth research question, an author-made questionnaire was prepared and for the fifth research question an author-made semi-structured interview (see Appendix B) was rigorously prepared and administered among $50 \%$ of the participants (face-to-face/online).

NDM-oriented reactance management questionnaire for $\mathrm{L} 2$ leamer

NDM-oriented reactance management questionnaire is a 45 -item questionnaire prepared by the author to address three major concepts of incivility prevention, resistance minimizing, and dissent management from three perspectives: learner-teacher anxiety, frustration, and selfdoubt (see Appendix A). The items were rated along a 6-step Likert scale which took between 40-45 minutes to answer. The first fifteen items on the questionnaire assess learner attitudes towards incivility prevention. These are termed incivility prevention $(a=68)$, the belief that learner incivility can be prevented by adopting some strategies with respect to learner-teacher anxiety, frustration, and self-doubt (e.g, "I think friendship strategy can prevent learner incivility and reduce learner-teacher anxiety). The second fifteen items on the questionnaire assess learners' attitudes towards resistance minimizing. These are termed resistance minimizing ( $a=77$ ), the belief that resistance can be minimized by adopting some strategies with respect to learner-teacher anxiety, frustration, and self-doubt (e.g. "I feel less resistance and frustration when a controversial subject is delivered unbiasedly"). The third fifteen items on the questionnaire assess learners' attitudes towards dissent management. These are termed dissent management $(a=70)$, the belief that one can manage dissent by adopting some strategies with respect to learner-teacher anxiety, frustration, and self-doubt (e.g. "I believe that catering for learners' dynamic motivational factors by the teacher can reduce the level of dissent and create 
a friendly environment with less anxiety and self-doubt"). Forty five subscales were tested for reliability in order to measure the internal consistency of them Reliabilities are displayed in Table 1. Reasonable reliabilities ranging from .69 to .78 were observed in line with alphas (Wigfield \& Guthrie, 1995) which are displayed in Table 1 with subscales of incivility prevention, resistance minimizing, and dissent management.

Table 1

Reliabilities for the NDM-oriented reactance management questionnaire Subscales

\begin{tabular}{lll}
\hline Subscale & Number of Items & Reliability \\
\hline Incivility Prevention & 15 & .69 \\
Resistance Minimizinc & 15 & .78 \\
Dissent Management & 15 & .70 \\
\hline
\end{tabular}

NDM-oriented reactance management interview

NDM-oriented reactance management interview is a 5-part survey (see Appendix B) prepared by the author to explore the possible efficiency of NDM-oriented reactance management strategies at three levels of preventing incivility, minimizing resistance, and managing dissent with regard to learner-teacher anxiety, frustration, and self-doubt. The first part elicits the interviewees' (i.e. teacher/learner) experiences of psychological reactance in classroom/online L2 teaching-learning by asking questions (e.g., Have you experienced/witnessed psychological reactance in terms of incivility, resistance, and dissent?). The elicited responses are interpreted and coded as $1=$ positive experience, $2=$ negative experience, $3=$ no experience which are termed as experience $(a=74)$.The second part elicits the interviewees' attitudes about the influence of NDM on psychological reactance management in classroom/online $\mathrm{L} 2$ teachinglearning with regard to previous experiences by asking questions (e.g., How influential is catering for individual motivational factors during L2 teaching-learning by telling about your own experiences?). The elicited responses are interpreted and coded as $1=$ influential, $2=$ 
uninfluential, $3=$ undecided. The third part elicits the interviewees' responses concerning the need for reactance management in classroom/online $\mathrm{L} 2$ teaching-learning by asking questions (e.g., How necessary is psychological reactance management in $L 2$ teaching-learning?). The elicited responses are interpreted and coded as 1=necessary, 2=not necessary, and $3=$ undecided. These are termed need $(a=72)$. The last item listed on the interview elicits the responses of the sample about the effectiveness of strategies at reactance management in $\mathbf{L}$ teaching-learning (e.g. eliminating test-oriented classes, providing novel activities, and improving learner achievement) by asking question (e.g., Do you think that eliminating test-oriented classes can facilitate preventing incivility, minimizing resistance, and managing dissent in face-toface/online L2 teaching-learning?). The elicited responses are interpreted and coded as $1=Y e s$, $2=\mathrm{No}$, and $3=$ Undecided. Reasonable reliabilities ranging from .70 to .74 were observed in line with alphas (Wigfield \& Guthrie, 1995) which are displayed in Table 2 with subscales ofLL ${ }^{1}$, LL $^{2}$, and LSL.

Table 2

Reliabilities for the NDM-oriented reactance management interview Subscales

\begin{tabular}{lll}
\hline Subscale & Number of Items & Reliability \\
\hline Experience & 2 & .74 \\
Influence & 3 & .70 \\
Need & 2 & .72 \\
Strategy & 3 & .75 \\
\hline
\end{tabular}

Data analysis procedures

Torun a thematic analysis, the collected qualitative-quantitative data was mixed into meta inferencesaccording to mixed data analysis procedures in line with Tashakkori and Teddlie(2003). Decisions on the inclusion/exclusion of qualitative or quantitative statistics were done based on iterative analyses. Accordingly, a parallel mixed data collection and analysis was donevia thematic analysis of collected data by integrating findings into metainferences. 


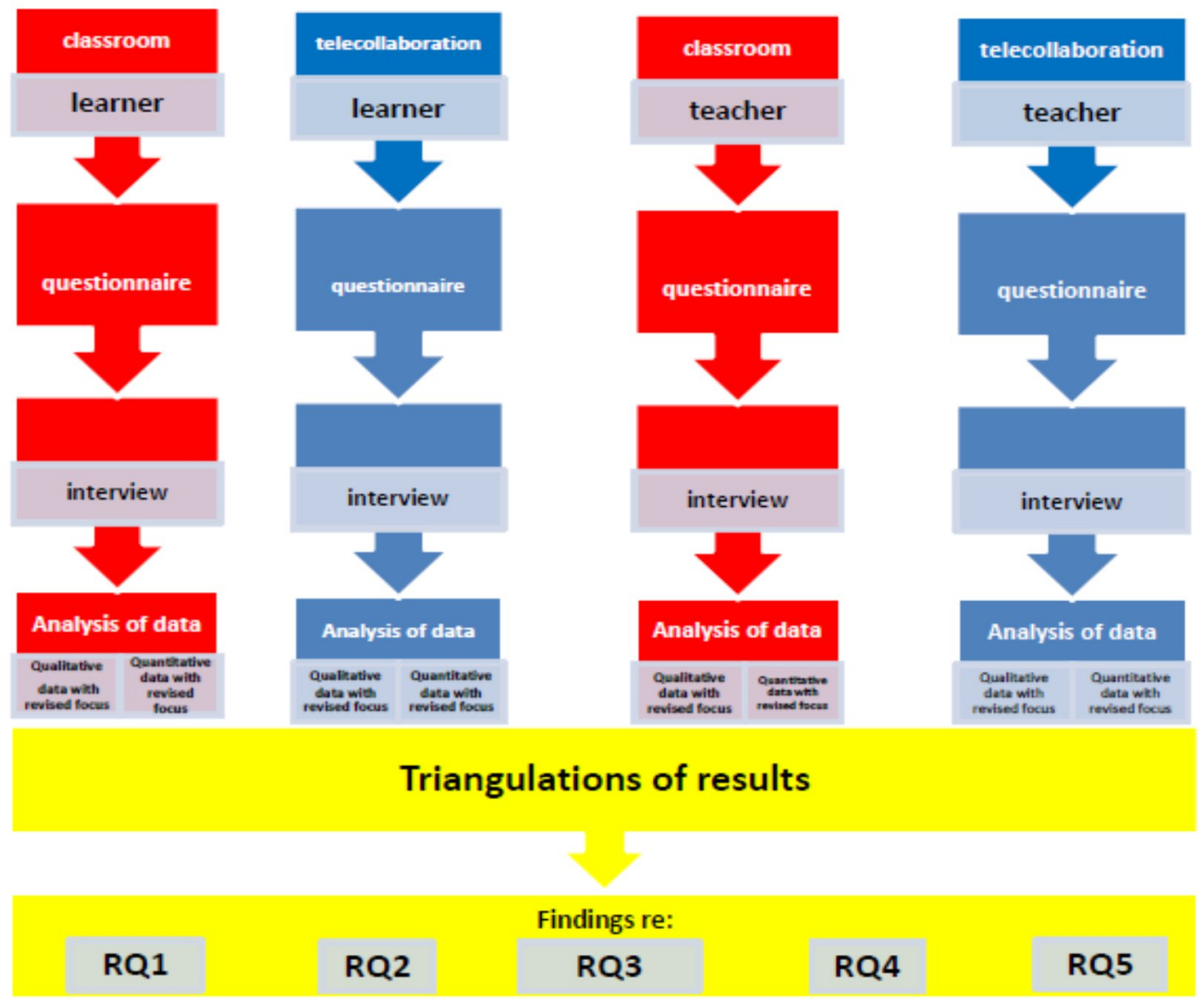

Figure 2. The visual representation of the study design

Quantitative analysis

To explore the relationship between NDM and reactance management at three categoriesthe following concepts were addressed: incivility prevention, resistance minimizing, and dissent management with regard to learner-teacher anxiety, frustration, and self-doubt. Given the unpaired and categorical nature of the collected data, the Pearson Chi square analysis was run to test whether any significant relationship exists between NDM and reactance management at three categories (incivility prevention, resistance minimizing and dissent management). Accordingy to describe the relationship between the two categorical variables a cross tabulation was used. 
Qualitative analytic plan

Reactance management-related statements were sorted and coded in the transcribed interviews. In keeping with Urdan and Mestas (2006), reactance management-related statements were considered as the scale for data analysis. The observed trend of elicited responses was coded in line with Saldaña (2013) to create a specified picture of reactance management-related statements and the corresponding subcategories in the primary level. To this end, subcoding techniques were used to code the data in keeping with Saldaña (2013) as a list of codes (see Appendix B). The presence or absence of the modified motivation strategy was identified by means of subcategories. Three experts assisted to ensure the inter-rater reliability and resolve the discrepancies and the final assessment showed $78 \%$ of inter-rater agreement.

\section{Results}

The results of analyzing participants' responses to the NDM-oriented reactance management questionnaire are displayed at three levels of civility prevention, resistance minimizing, and dissent management. The results showed that the majority of the sample $(M=2.094)$ have positive attitude about the NDM-oriented statements in terms of preventing civility, minimizing resistance, and managing dissent. Observing a positive attitude among the majority of the participants reflects the need to further elaborate on the subject in future studies with respect to nonlinearity and dynamicity of L2 motivation in classroom and online L2 teaching-learning contexts. The mean of the observed standard deviations $M=0.741$ (see table.3) shows that there is no polarized responses and the majority of the participants believe in the efficiency of NDM-oriented strategies to manage reactance. 
Table 3

Descriptive Statistic

\begin{tabular}{|c|c|c|c|c|c|}
\hline & $\mathrm{N}$ & Minimum & Maximum & Mean & $\begin{array}{l}\text { Std. } \\
\text { Deviation }\end{array}$ \\
\hline Online Teacher & 8 & 1.00 & 3.00 & 1.6250 & .74402 \\
\hline Prevent Incivility & & & & & \\
\hline $\begin{array}{l}\text { Online Learner } \\
\text { Prevent Incivility }\end{array}$ & 65 & 1.00 & 5.00 & 1.8923 & 1.06247 \\
\hline $\begin{array}{l}\text { Class Teacher } \\
\text { Prevent Incivility }\end{array}$ & 34 & 2.00 & 4.00 & 3.1471 & .55772 \\
\hline $\begin{array}{l}\text { Class Learner } \\
\text { Prevent Incivility }\end{array}$ & 168 & 1.00 & 3.00 & 1.7143 & 64875 \\
\hline $\begin{array}{l}\text { Online Teacher } \\
\text { Minimize resistance }\end{array}$ & 8 & 1.00 & 2.00 & 1.8750 & .35355 \\
\hline $\begin{array}{l}\text { Online Learner } \\
\text { Minimize Resistance }\end{array}$ & 65 & 1.00 & 5.00 & 2.0308 & 1.03031 \\
\hline $\begin{array}{l}\text { Class Teacher } \\
\text { Minimize Resistance }\end{array}$ & 34 & 2.00 & 4.00 & 2.8824 & 68599 \\
\hline $\begin{array}{l}\text { Class Learner } \\
\text { Minimize Resistance }\end{array}$ & 168 & 1.00 & 3.00 & 1.5298 & .61834 \\
\hline $\begin{array}{l}\text { Online Teacher } \\
\text { Manage Dissent }\end{array}$ & 8 & 1.00 & 3.00 & 2.3750 & .91613 \\
\hline $\begin{array}{l}\text { Online Learner } \\
\text { Manage Dissent }\end{array}$ & 65 & 1.00 & 5.00 & 2.0769 & 1.03543 \\
\hline $\begin{array}{l}\text { Class Teacher } \\
\text { Manage Dissent }\end{array}$ & 34 & 1.00 & 4.00 & 2.7941 & .84493 \\
\hline $\begin{array}{l}\text { Class Learner } \\
\text { Manage Dissent }\end{array}$ & 168 & 1.00 & 2.00 & 1.1964 & .39848 \\
\hline Valid N (listwise) & 8 & & & & \\
\hline
\end{tabular}

To find out whether there is a relationship between NDM-oriented strategies and civility prevention, resistance minimizing, and dissent management the elicited responses were 
analyzed correlations analysis and the results were displayed in the following visual representation of the correlation results between learner-teacher attitudes towards reactance management via NDM:

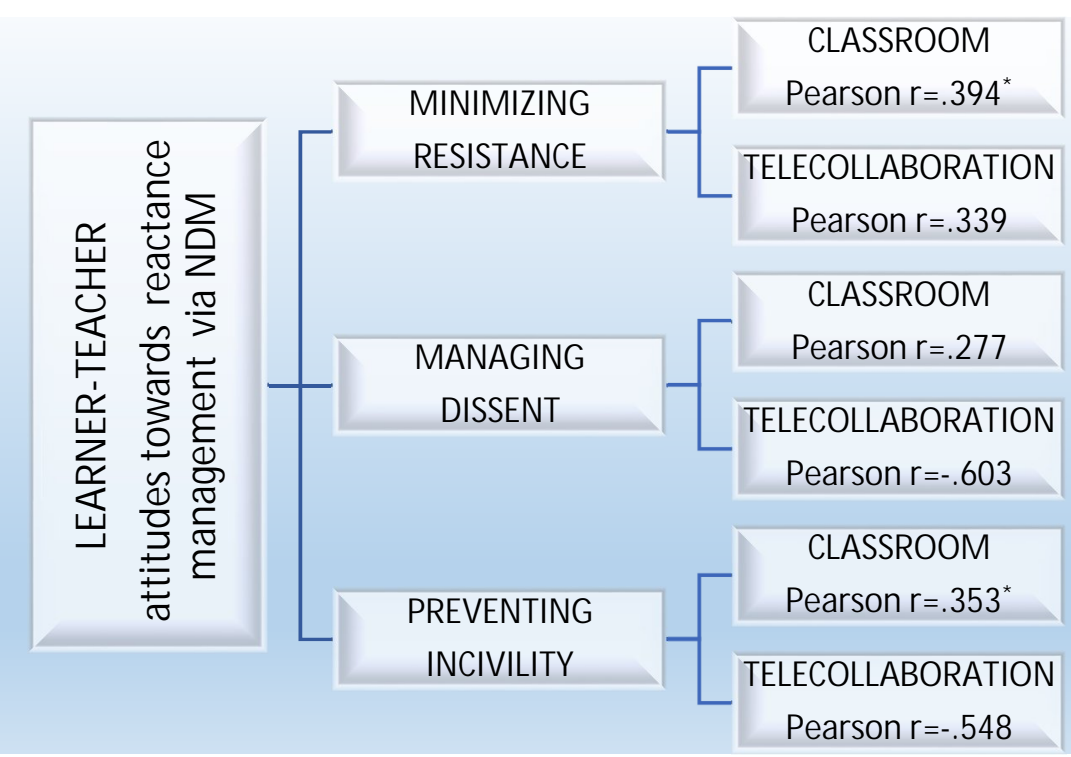

Figure 3. Learner-Teacher attitudes towards reactance management via NDM

A quick look at the above diagram shows that there is statistically significant relationship between NDM-oriented strategies and civility prevention, resistance minimizing, and dissent management based on the elicited responses from learner-teacher participants. Therefore, both groups believe that NDM-oriented strategies have the potential to manage reactance in classroom context. However, in telecollaborative context, with the exception of minimizing resistance category (which shows positive attitudes of learner-teacher participants) in two other categories there is negative relationship in the elicited responses from the learners and teachers. This reflects teachers' orientation towards monologic instruction instead of dialogic one which ends up in a non-learn-friendly context with high risk of causing reactance-inducing statements/conditions during $\mathbf{L}$ teaching-learning. Tracing for possible relationships between classroom and online learners' responses about reactance management by NDM, led to 
discovering positive views among all participants regardless of their contexts (classroom/telecollaboration) and position (teacher/learner).

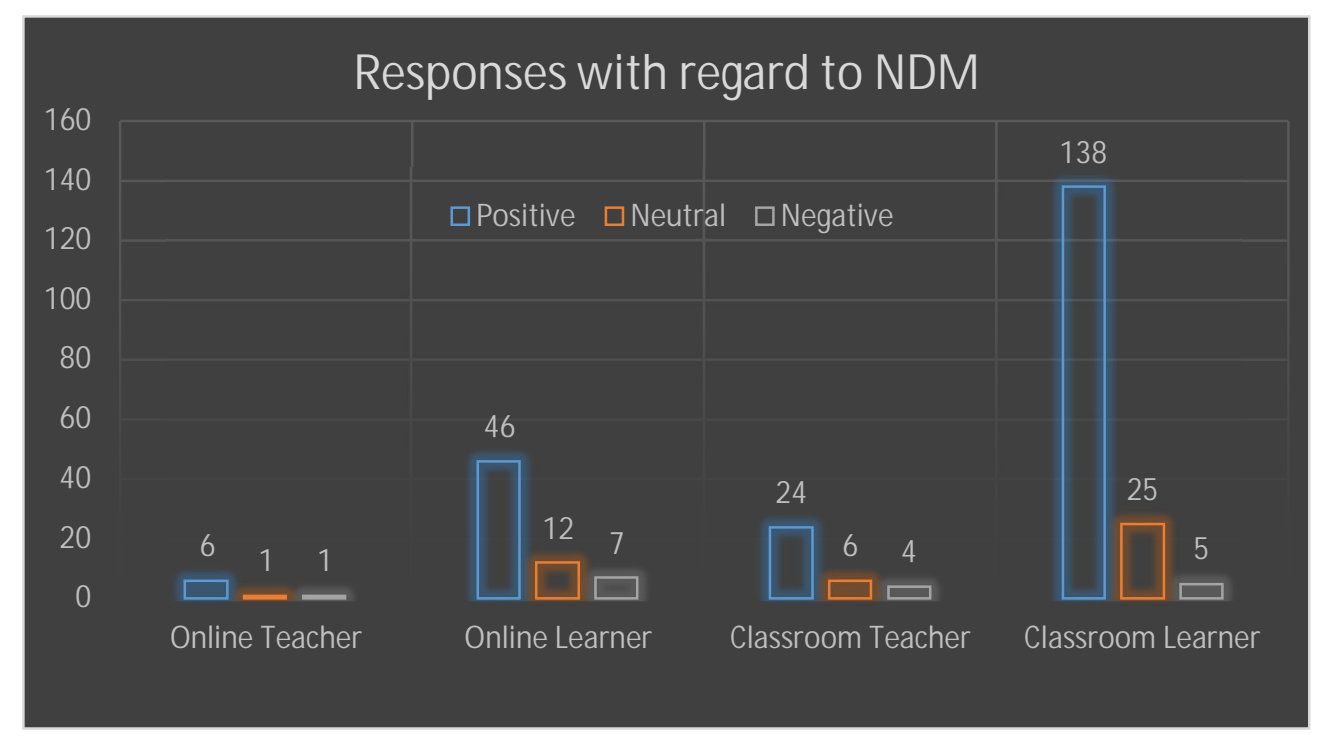

Figure 4 classroom and online learners' responses with regard to NDM

To cross-validate the collected data and capture different dimensions of reactance management via NDM from teacher-learner perspectives methodological triangulation was used. Triangulation facilitates gaining a good understanding of different perspectives, accordingly different participants ( $\mathrm{L} 2$ teachers and learners) from different contexts (i.e. classroom and telecollaboration) were incorporated in the study to strengthen the results from various aspects. The elicited responses from the interviewees with respect to their experiences revealed that 


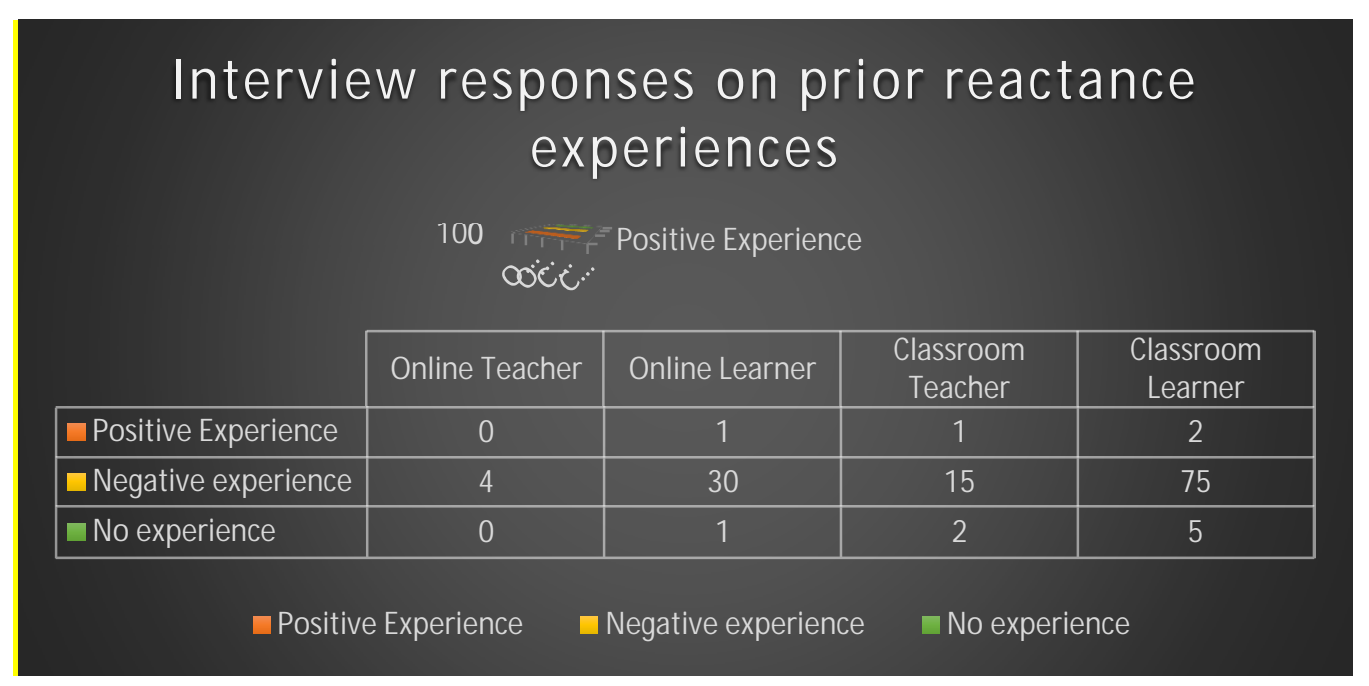

Figure 5 Interview responses on prior reactance experiences

the majority of learner-teacher participants of the present study had negative reactance-related experiences which serves as an evidence for the existence of reactance within classroom and online L2 teaching-learning contexts. Therefore, further studies on the possible reasons behind this less-analyzed factor is essential. The elicited responses concerning the influence of psychological reactance' in L2 teaching-learning showed that: 


\section{Interview responses on the influence of Reactance \\ in L2 teaching-learning}

\section{口influential $\quad$ uninfluential $\quad$ undecided}

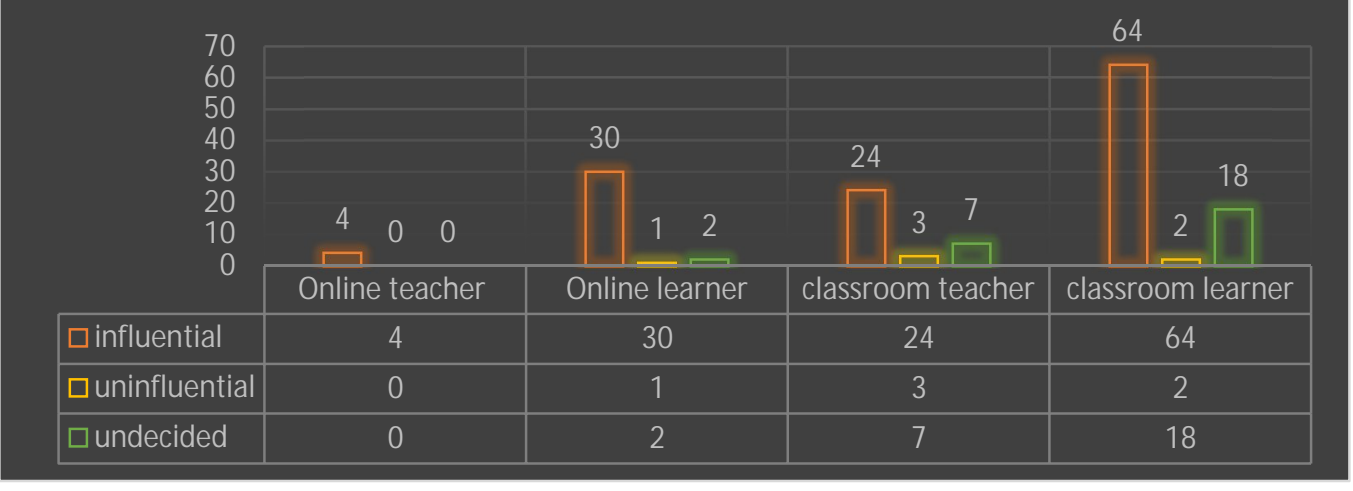

Figure 6 Interview responses on the influence of Reactance in $L 2$ teaching-learning

Both contexts revealed a positive attitude towards the significance of psychological reactance as an influential factor in $\mathrm{L} 2$ teaching-learning and both teachers and learners believe that this psychological factor is influential and needs to be addressed both to facilitate instruction and to reduce resistance, incivility, and dissent among the learner group. Similarly the elicited responses from the third category of the interview (the need for managing reactance) confirmed the need for adopting strategies by both teachers and learners in both contexts. The last part of the interview was an attempt to elicit participants' responses concerning the efficiency of four categories of strategies in managing reactance: 


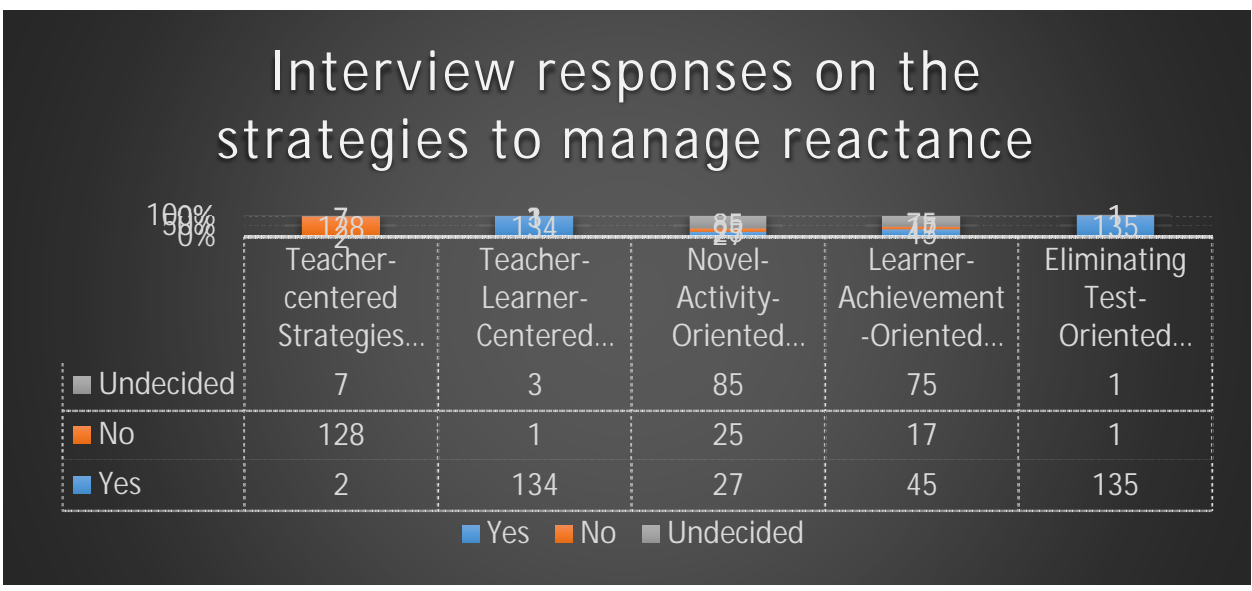

Figure 7 Interview responses on the strategies to manage reactance

Eliminating the test-oriented classes is the most salient result of the study concerning the suggested strategies by the interviewees. Based on the expressed views (implicitly/explicitly), learners believe that originally there is a negative pressure/atmosphere in test-oriented classes which is increased when learners are threatened by reactance-inducing statements or when they find out about a systematic test-score-manipulation by the teacher(s) for a variety of reasons (e.g. discrimination, fleeing from responsibility, blocking any argument, expecting obedience, etc.). According to the obtained results, there is a consensus among teachers and learners in classroom and online environments concerning the efficiency of NDM as a facilitator to prevent incivility, minimize resistance, and manage dissent.

\section{Discussion}

Based on results, the study confirms the effectiveness of NDMSs as a valid tool to minimize and manage psychological reactance in classroom and telecollaborative contexts. Accordingy, it can safely be concluded that restraining learner's freedom of voice, preferences, and options within a demotivating undemocratic L2 classroom causes oppositional behaviors which needs to be avoided on the part of the teacher in both contexts. The study confirms positive opinion among the sample under the study on the applicability of NDMSs as a minimizing and managing tool for 
managing psychological reactance. The study suggests new pedagogical reforms in terms of teachers' belief systems about teaching practices (Buehl \& Beck, 2015; Fives \& Gill, 2015; Fives, Lacatena, \& Gerard, 2015) and applying learner-friendly models of practice (e.g. FonF practice model) with a focus on nonlinearity and dynamicity of motivation which differs from learner to learner (Author, 2019). Given the thin literature apropos of nonlinearity and dynamicity of L2 motivation, future researches are suggested to examine the use and contextualization of NDMSs in different learning contexts and at different language proficiency levels. The main goal is to recruit the potential behind the diversity of $L 2$ motivation self types which has been overlooked in popular $\mathbf{L}$ motivation theories such $\mathbf{L}$ motivation self system for the benefit of the $L 2$ learners by creating a an every-learner-motivated classroom.

\section{Implications of the Study}

For Research

Given the obtained results, the first research implication is the need to conduct further studies in terms of gender-related differences in reactance management in classroom and telecollaborative $L 2$ teaching environments. Besides that with regards to similar characteristics of anti-ought-to self and NDM in terms of nonlinearity and dynamicity on the one hand and similar characteristics of anti-ought-to self and psychological reactance theory in terms of oppositional behavior, further publications are necessary to clarify their connections with regard to L2 learning motivation. Since L2MSS (Ushioda, 2013) and psychologica RT (Thompson, 2017) share the same individual-oriented basis their integration into a model of meeting motivational needs and minimizing oppositional behavior is a promising research goal.Given the findings of the study the first theoretical implication is the need to create a conceptualized and contextualized model of integrating and recruiting the potential behind NDM as a motivational state (Bahari, 2018a). The intertwined model of reactance (Dillard \& Shen, 2005; Eagly, Mladinic, \& Otto, 1994; Kim, Levine, \& Allen, 2013; Rains, 2013; Quick \& Considine, 2008; Quick \& Stephenson, 2007; Rains \&Turner, 2007) and NDM requires further studies to test other variables (e.g. self-efficacy, demotivation) which might facilitate reactance 
management in classroom/telecollaborative contexts and create a more motivating learning environment. Such a model can not only cater for motivational needs of L2 learner but also preserve Learner autonomy (Chartrand, Dalton, \& Fitzsimons, 2007) without resorting to oppositional behaviors. Accordingly with respect to the newly introduced teaching-learning horizons for traditional L2 learner group, such as online discourse, virtual motivational mechanisms, and identity-forming processes, further studies are required to theorize telecollaboaration-oriented teaching-learning models to facilitate learner autonomy by employing NDM to meet the pedagogical needs of telecollaborative teacher-learner.

\section{For pedagogy}

The most salient pedagogical implication of the study is about strategies to manage reactance within classroom/telecollaborative L2 teaching. According to the obtained results test-oriented classes have negative effect on reactance management and increase the emergence of incivility, dissent and resistance along with learner-teacher self-doubt, anxiety, and frustration. Most of the learner-participants believed that such classes not only provide some teachers with a manipulative tool (i.e. test score manipulation) to threaten or oppress learner autonomy but also lifts the pressure from teachers to prepare novel activities for the learner group. Some of the teacher-participants also implicitly confirmed the existence of such reactance-inducing conditions in $\mathbf{L}$ teaching-learning contexts. Therefore, some pedagogical reformations are needed to address these anti-learner features of test-oriented classes which affects $L 2$ teachinglearning environments. The second implication is that reinforcing NDM has the potential to prevent incivility, minimize resistance, and manage dissent along with catering for motivational needs of the 12 learners. NDM-oriented pedagogy ensures learner-friendly environments where anti-ought-to-selves are neither ignored nor restrained instead they are minimized and redirected in line with NDM at individual level (Bahari, 2018b). In keeping with the dynamicity and nonlinearity of learner's motivation, the third implication of the study is the need to foster collaborative meaning-making process through dialogic discourse instead of traditionally established monologic discourse in classroom/tellecollaborative $L 2$ teaching-learning. While the 
former discourse type permits argumentative virtues the latter one fosters teacher-centered teaching beliefs.

\section{Conclusion}

According to the obtained results, it can be safely concluded that restraining learner's freedom of voice, preferences, and options causes reactance and demotivation among L2 learners however, catering for NDM facilitates reactance management and creates a learner-friendly L2 teaching-learning context. To this end, new pedagogical reforms in terms of teachers' belief systems about teaching practices (Buehl \& Beck, 2015; Fives \& Gill, 2015; Fives, Lacatena, \& Gerard, 2015) despite the lack of support from socioeconomic contexts (Price, 2012) need to be conducted by integrating and embedding NDM-oriented $L 2$ teaching strategies to minimize reactance and develop a learner-friendly classroom and tellecollaborative $L 2$ teaching-learning contexts.

The main limitation of the study was the unwillingness of the teachers accustomed to teachercentered and test-oriented approach of $L 2$ teaching to cooperate in the project which reduced the number of the possible participants to a large extent. Unfortunately, some teachers despite the presence of computer-assisted language learning tools and affordances which can facilitate language learning on the part of the learners, prefer to impose rote learning on the learners and silence any objection via test scores.

\section{Acknowledgment}

The author would like to thank the anonymous reviewers for their insightful comments and suggestions to improve the paper. Author also wishes to thank his wife and daughter, Mona and Anahita for their patience and kindness. Author also appreciates motivating professors who create learner-friendly environment and avoid demotivating and stirring oppositional behavior among learners. 


\section{References}

Achacoso, M. V. (2002). "What do you mean my grade is not an A?" An investigation of academic entitlement, causal attributions, and self-regulation in college students. (Ph.D.), The University of Texas at Austin

Bahari, A. (2019). FonF practice model from theory to practice: CALL via focus on form approach and nonlinear dynamic motivation to develop listening and speaking proficiency. Computers \& Education, 130(3), 40-58. https://doi.org/10.1016/j.compedu.2018.11.009

Bahari, A. (2018a). Nonlinear dynamic motivation-oriented telecollaborative model of language learning via formulaic sequences to foster learner autonomy. The Journal of Teaching English with Technology. 18(3), 65-81, http://www.tewtjournal.org

Bahari, A. (2018b). Sacred text motivation for general 12 learners: a mixed methods study. Joumal of Academic Ethics,16(4), 1-31. https://doi.org/10.1007/s10805-018-9316-3

Bahari, A. (2018c). Developing listening and speaking via a psycho-socio-cultural learning model based on non-linear dynamic motivation. Jordan Joumal of Modem Languages and Literature, 10(2),115-135.

Bahari, A. (2018d). Nonlinear dynamic motivation-oriented learner-centered L2 classroom Journal of Uludag University Faculty of Education, 32(2), 30-46.

Bjorklund, W. L., \& Rehling D. L. (2009). Student perceptions of classroom incivility. College Teaching, 58(1),15-18.

de Bot, K., Lowie, W. \& Verspoor, M. (2007). A dynamic systems theory approach to second language acquisition. Bilingualism: Language and Cognition 10 (1), 7-21.

de Bot, K. \& Larsen Freeman, L. (2011). Researching second language development from a dynamic systems theory perspective. In M.H. Verspoor, K. de Bot and W. Lowie (eds) A Dynamic Approach to Second Language Development: Methods and Tedniques (pp. 5-24). Amsterdam John Benjamins.

Brehm J. W. (1966). A theory of psydhological readance New York: Academic Press.

Buehl, M. M., \& Beck, J. S. (2015). The relationship between teachers' beliefs and teachers' practices. In H. Fives \& M. Gregoire Hill (Eds.), International handbook of research on teachers' beliefs (pp. 66-84). New York, NY: Routledge.

Chang, L. Y. H. (2010). Group processes and EFL learners' motivation: A study of group dynamics in EFL classrooms. TESOL Quarterly, 44(1), 129-154. 
Chartrand, T. L., Dalton, A. N., \& Fitzsimons, G. J. (2007). Nonconscious relationship reactance: When significant others prime opposing goals. Jourmal of Experimental Social Psychology, 43, 719-726.

Chowning K., \& Campbell, N. J. (2009). Development and validation of a measure of academic entitlement: Individual differences in students' externalized responsibility and entitled expectations. Joumal of Educational Psychology, 101(4), 982-997.

Ciani, K. D., Summers, J. J., \& Easter, M. A. (2008). Gender differences in academic entitlement among college students. The Journal of Genetic Psychology, 169(4),332-344.

Clark, C. M., \& Springer, P. J. (2007). Thoughts on incivility: Student and faculty perceptions of uncivil behavior in nursing education. Nursing Education Perspectives, 28(2), 93-97.

Cortina, L. M., Magley, V. J., Williams, J. H., \& Langhout, R. D. (2001). Incivility at the workplace: Incidence and impact. Journal of Occupational Health Psychology, 6, 64-80.

Dillard, J. P., \& Shen, L. (2005). On the nature of reactance and its role in persuasive health communication.Communication Monographs, 72, 144-168. doi:10.1080/03637750500111815

Dornyei, Z. (2009). The 12 motivational self-system In Z. Dornyei, \& E. Ushioda (Eds.), Motivation, language identity and the $L 2$ self (pp. 9-42). Bristol: Multilingual Matters.

Dörnyei, Z., Csizér, K., \& Németh, N. (2006). Motivation, language attitudes and globalisation: A Hungarian perspective. Clevedon, UK: Multilingual Matters.

Dörnyei, Z., \& Ryan, S. (2015). The psychology of the language learner revisited. NewYork, NY: Routledge.

Eagly, A. H., Mladinic, A., \& Otto, S. (1994). Cognitive and affective bases of attitudes towardsocial groups and social policies. Joumal of Experimental Social Psychology, 30, 113137.doi:10.1006/jesp.1994.1006

Feldmann, L. J. (2001). Classroom civility is another of our instructor responsibilities. College Teaching, 49, 137-140.

Fives, H., \& Gill, M. G. (Eds.). (2015). International handbook of research on teachers' beliefs. New York, NY: Routledge.

Fives, H., Lacatena, N., \& Gerard, L. (2015).Teachers' beliefs about teaching (and learning). In H. Fives \& M. G. Gill (Eds.), International handbook of research on teachers' beliefs (pp. 249265). New York, NY: Routledge. 
Fong, C. J., Lin, S., \& Engle, A. R. (2016). Positioning identity in computer-mediated discourse among ESOL learners. Language Leaming \& Tednology, 20(3), 142-158.

Freiermuth, M. R., \& Huang, H. C. (2012). Bringing Japan and Taiwan closer electronically: A look at an intercultural online synchronic chat task and its effect on motivation. Language Teadhing Research, 16(1), 61-88. doi:10.1177/1362168811423341

Fusella, P.V. (2013). Dynamic Systems Theory in Cognitive Science: Major Elements, Applications, and Debates Surrounding a Revolutionary MetaTheory. Dynamical Psychology 2013 - dynapsyc.org. See http://dynapsyc.org/2013/Fusella.pdf

Garton, L., Haythornthwaite, C., \& W ellman, B. (1997). Studying online social networks. Joumal of Computer-mediated Communication, 3(1). doi:10.1111/j.1083-6101.1997.tb00062.x

Greenberger, E., Lessard, J., Chen, C., \& Farruggia, S. P. (2008). Self- entitled college students: Contributions of personality, parenting, and motivational factors. Journal of Youth and Adolescence, 37(10),1193-1204.

Griffiths, C. (2013). The strategy factor in successful language learning. Bristol, England: Multilingual Matters.

Henry, A., Dornyei, Z., \& Dayydenko, S. (2015). The anatomy of directed motivational currents:Exploring intense and enduring periods of L2 motivation. The Modem Languagejoumal, 99, 329-345.

Hiver, P. (2015). Attractor states. In Z. Dörnyei, P. Maclntyre and A. Henry (eds) Motivational Dynamics in Language Learning (pp. 20-28). Bristol: Multilingual Matters.

Jarrell, D., \& Freiermuth, M. R. (2005). The motivational power of Internet chat. RELC Journal, 36(1), 59-72. doi:10.1177/0033688205053482

Jiang Y., \& Dewaele, J. M. (2015). What lies bubbling beneath the surface? A longitudinal perspective on fluctuations of ideal and Ought-to $L 2$ self among Chinese learners ofEnglish. International Review of Applied Linguistics in Language Teaching, 53, 331-354.

Jost, J. T., Banaji, M. R., \& Nosek, B. A. (2004). A decade of systemjustification theory: Accumulated evidence of conscious andunconscious bolstering of the status quo. Political Psychology,25, 881-919.

Kay, A. C., Gaucher, D., Peach, J. M., Friesen, J., Laurin, K., Zanna,M. P., \& Spencer, S. J. (2009). Inequality, discrimination, andthe power of the status quo: Direct evidence for a motivationto view what is as what should be. Journal of Personality andSocial Psychology, 97, 421-434.

Kikuchi, K. (2009). Listening to our learners' voices: What demotivates Japanese high school students? Language Teaching Research, 13, 453-471.

Kikuchi, K. (2015). Demotivation in Second Language Acquisition. Bristol: Multilingual Matters. 
Kim S., Levine, T., \& Allen, M. (2013). Comparing separate process and intertwined modelsfor reactance. Communication Studies, 64, 273-295. doi:10.1080/10510974.2012.755639

Kim, K. J. (2009). Demotivating factors in secondary English education. English Teadhing 64(4), 249-267.

Klimanova, L., \& Dembovskaya, S. (2013). L2 identity, discourse, and social networking in Russian. Language Leaming \& Tednology, 17(1), 69-88. Retrieved from http://lt.msu.edu/issues/february2013/klimanovadembovskaya.pdf

Kramsch, C., A'Ness, F., \& Lam, W. S. E. (2000). Authenticity and authorship in the computermediated acquisition of $L 2$ literacy. Language Leaming \& Technology, 4(2), 78-104. Retrieved from http://lt.msu.edu/vol4num2/kramsch/default.html

Larsen-Freeman, D. \& Cameron, L. (2008). Complex Systems and Applied Linguistics. Oxford: Oxford University Press

Laurin, K., Kay, A.C., Proudfoot, d., \& Fitzsimons, G,J. (2013). Response to restrictive policies: Reconciling system justification and psychological reactance. Organizational Behavior and Human Decision Processes 122, 152-162.

Lippmann, S., Bulanda, R. E., \& Wagenaar, T. C. (2009). Student entitlement: Issues and strategies for confronting entitlement in the classroom and beyond. College Teadhing 57(4), 197-204.

Lyubomirsky, S., \& Layous, K. (2013). How do simple positive activities increase well-being? Current Directions in PsychologicalScience, 22, 57-62. doi:10.1177/0963721412469809

Maclntyre, P.D. \& Legatto, J.J. (2011). A dynamic system approach to willingness to communicate: Developing and idiodynamic method to capture rapidly changing affect. Applied Linguistics 32 (2),149-171.

Meunier, L. (1998). Personality and motivational factors in electronic networking. In J. Muyskens (Ed.), New ways of learning and teaching: Focus on tedhnology and foreign language education (pp. 63-126). Boston, MA: Heinle \& Heinle.

Miron, A. M., \& Brehm, J. W. (2006). Reactance theory-40 years later. Social Psychology (formerly Zeitschrift für Sozialpsychologie), 37, 9-18.

Moskovsky, C., Racheva, S., Assulaimani, T., \& Harkins, J. (2016). The L2 Motivational Self System and L2Achievement: A study of Saudi EFL learners. The Modem Language Joumal. Advanced online publication.doi: 10.1111/modl.12340

Nutt, C. M. (2013). Stop the madness! College faculty and student perceptions of classroom incivility. Bourbonnais, Illinois: Olivet Nazarene University.

Oxford, R. (2017). Teadhing and researching language learming strategies: Self-regulation in context (2nd ed.). New York: Routledge. 
Price, H. E. (2012). Principal-teacher interactions: How affective relationships shape principal and teacher attitudes. Education \& Educational Research, 48(1), 39-85.

Quick, B. L., \& Considine, J. R. (2008). Examining the use of forceful language when designingexercise persuasive messages for adults: A test of conceptualizing reactance arousal as atwo-step process. Health Communication, 23, 483-491. doi:10.1080/10410230802342150

Quick, B. L., \& Stephenson, M. T. (2007). Further evidence that psychological reactance can bemodeled as a combination of anger and negative cognitions. Communication Research, 34,255-276. doi:10.1177/0093650207300427

Quoidbach, J., Mikolajczak, M., \& Gross, J. J. (2015). Positive interventions: An emotion regulation perspective. Psychological Bulletin, 141, 655-693. doi:10.1037/a0038648

Rains, S. A. (2013). The nature of psychological reactance revisited: A meta-analytic review.Human Communication Research, 39, 47-73. doi:10.1111/j.1468-2958.2012.01443.x

Rains, S. A., \& Turner, M. M. (2007). Psychological reactance and persuasive health communication:A test and extension of the intertwined model. Human Communication Research,33, 241-269. doi:10.1111/j.1468-2958.2007.00298.x

Rusk, R. D., \& Waters, L. (2015). A psycho-social system approach to well-being: Empirically deriving the five domains of positive functioning. The Journal of Positive Psychology, 10, 141152. doi:10.1080/17439760.2014.920409

Saldaña, J. (2013). The coding manual for qualitative researchers (2nd ed.). Thousand Oaks, CA: Sage Publications Inc.

Schunk, D. H., \& Zimmerman, B. J. (2012). Motivation and self-regulated leaming: Theory, research, and applications. New York: Routledge.

Sheldon, K., Boehm J., \& Lyubomirsky, S. (2013). Variety is the spice of happiness: The hedonic adaptation prevention (HAP) model. In S. A. David, I. Boniwell, \& A. C. Ayers (Eds.), Oxford handbook of happiness (pp. 901-914). Oxford: Oxford University Press.

Tashakkori, A. \& Teddlie, C. (2003). Handbook of Mixed Methods in Sodial \&Behavioral Research. Thousand Oaks: Sage.

Thompson, A. S. (2017). Don't tell me what to do! The anti-ought-to self and language learningmotivation, Systemhttp://dx.doi.org/10.1016/j.system2017.04.004

Thompson, A. S., \& Erdil-Moody, Z. (2016). Operationalizing multilingualism: Language learning motivation in Turkey. International Joumal of Bilingual Education and Bilingualism 19(3), 314331. http://dx.doi.org/10.1080/13670050.2014.985631.

Thompson, A. S., \& Vasquez, C. (2015). Exploring motivational profiles through language learning narratives. Modem Language Joumal, 99(1), 158174.https://doi.org/10.1111/modl.12187. 
Trang, T. T. T., \& Baldauf, R. B. (2007). Demotivation: Understanding resistance to English language learning the case of Vietnamese students. The Joumal of Asia TEFL, 4(1), 79-105.

Urdan, T., \& Mestas, M. (2006). The goals behind performance goals. Journal of Educational Psychology, 98(2), 354-365. http://dx.doi.org/10.1037/0022-0663.98.2.354

Ushioda, E. (2013). Christian faith, motivation and L2 learning: Personal, social and research perspectives. In M. S. Wong C. Kristjansson, \& Z. Dörnyei (Eds.), Christian faith and English languageteaching and leaming: Research on the interrelationshipof religion and ELT (pp. 223-229). New York: Routledge/Taylor \& Francis.

Ushioda, E., \&Dornyei, Z. (2017). Beyond Global Engish: Motivation to Learn Languages in a Multicultural World: Introduction to the Special Issue. The Modem Language Joumal, 101, 3. DOI: $10.1111 / \mathrm{modl} .12407$

Warschauer, M., Turbee, L., \& Roberts, B. (1996). Computer learning networks and student empowerment. System, 24(1), 1-14. doi:10.1016/0346-251X(95)00049-P

Wigield, A., \& Guthrie, J. T. (1995). Dimensions of dildren's motivations for reading:An initial study (Research Rep. No. 34). Athens, GA: National Reading Research Center.

Wigiield, A., \& Guthrie, J.T. (1997). Relations of children's motivation for reading to the amount and breadth of their reading. Journal of Educational Psychology, 89(3), 420-432.

Wortman, C. B., \& Brehm J. W. (1975). Responses to uncontrollableoutcomes: An integration of reactance theory and the learnedhelplessness model. In L. Berkowitz (Ed.), Advances in experimentalsocial psychology (Vol. 8, pp. 236-277). New York, NY:Academic Press.

\section{Appendices}

Appendix A NDM-oriented reactance management questionnaire for $L 2$ teacher-learner 
Journal of Educational, Health and Community Psychology

Vol 8, No 1, 2019 E-ISSN 2460-8467

Akbar Bahari

Dear teacher/learner kindly answer all items whether statements are about teachers or learners.

NDM stands for nonlinear dynamic motivation which refers to changing nature of motivation in learner.

Table 4 NDM-oriented reactance management questionnaire

\begin{tabular}{|c|c|c|c|c|c|c|c|c|}
\hline Strategy & $\begin{array}{l}\text { Focus of } \\
\text { statements }\end{array}$ & Statements & $\frac{8}{8}$ & $\frac{b}{8}$ & 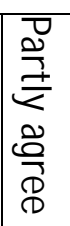 & 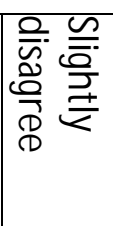 & $\begin{array}{l}\frac{0}{4} \\
\frac{0}{8} \\
\frac{8}{B}\end{array}$ & 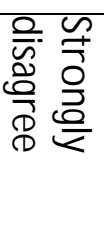 \\
\hline \multirow[t]{10}{*}{$\begin{array}{l}\text { Incivility } \\
\text { Prevention }\end{array}$} & Anxiety & $\begin{array}{l}\text { I think catering for NDM along with } \\
\text { applying friendship strategy can } \\
\text { prevent learner incivility and reduce } \\
\text { learner-teacher anxiety }\end{array}$ & & & & & & \\
\hline & Anxiety & $\begin{array}{l}1 \text { believe that test-oriented classes act } \\
\text { against NDM and increase learner } \\
\text { anxiety and learner incivility }\end{array}$ & & & & & & \\
\hline & Anxiety & $\begin{array}{l}\text { I think reactance-inducing statements } \\
\text { by teachers act against NDM and } \\
\text { increase anxiety and incivility }\end{array}$ & & & & & & \\
\hline & Anxiety & $\begin{array}{l}\text { I think reactance-inducing statements } \\
\text { by learners act against NDM and } \\
\text { increase anxiety and incivility }\end{array}$ & & & & & & \\
\hline & Anxiety & $\begin{array}{l}\text { think test-score manipulation by } \\
\text { teachers act against NDM and causes } \\
\text { anxiety and incivility }\end{array}$ & & & & & & \\
\hline & Frustration & $\begin{array}{l}\text { think low achievement has } \\
\text { demotivating effects and causes } \\
\text { frustration and incivility among } \\
\text { learners therefore improving learner } \\
\text { achievement can prevent incivility }\end{array}$ & & & & & & \\
\hline & Frustration & $\begin{array}{l}\text { I think lack of novel activities in } L_{2} \\
\text { teaching causes frustration among } \\
\text { learners which leads to incivility }\end{array}$ & & & & & & \\
\hline & Frustration & $\begin{array}{l}\text { I believe that restrictive classes act } \\
\text { against NDM and increase learner } \\
\text { frustration and learner incivility }\end{array}$ & & & & & & \\
\hline & Frustration & $\begin{array}{l}\text { think test-score manipulation by } \\
\text { teachers act against NDM and causes } \\
\text { frustration and incivility }\end{array}$ & & & & & & \\
\hline & Frustration & I think meeting learners' motivational & & & & & & \\
\hline
\end{tabular}




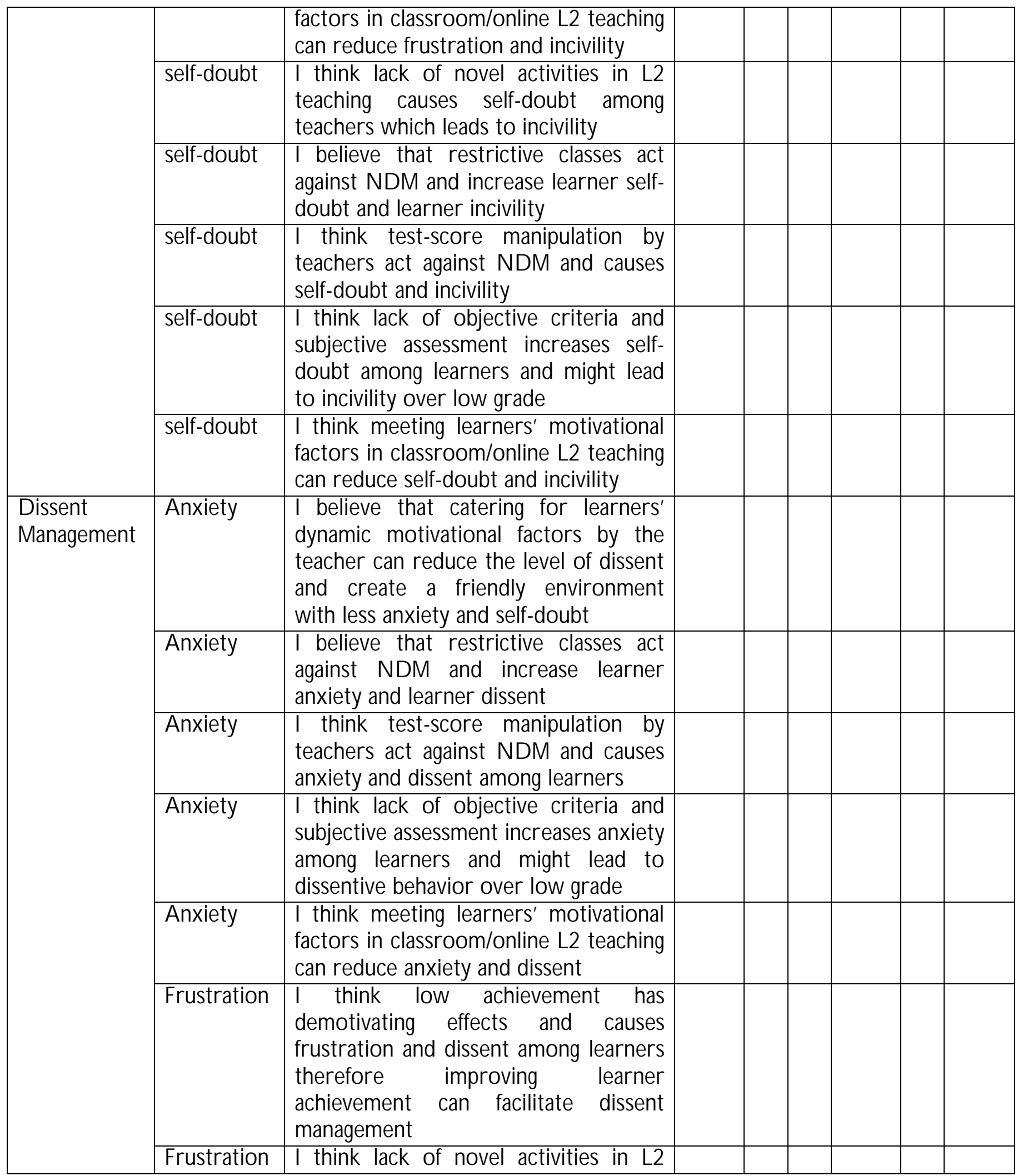




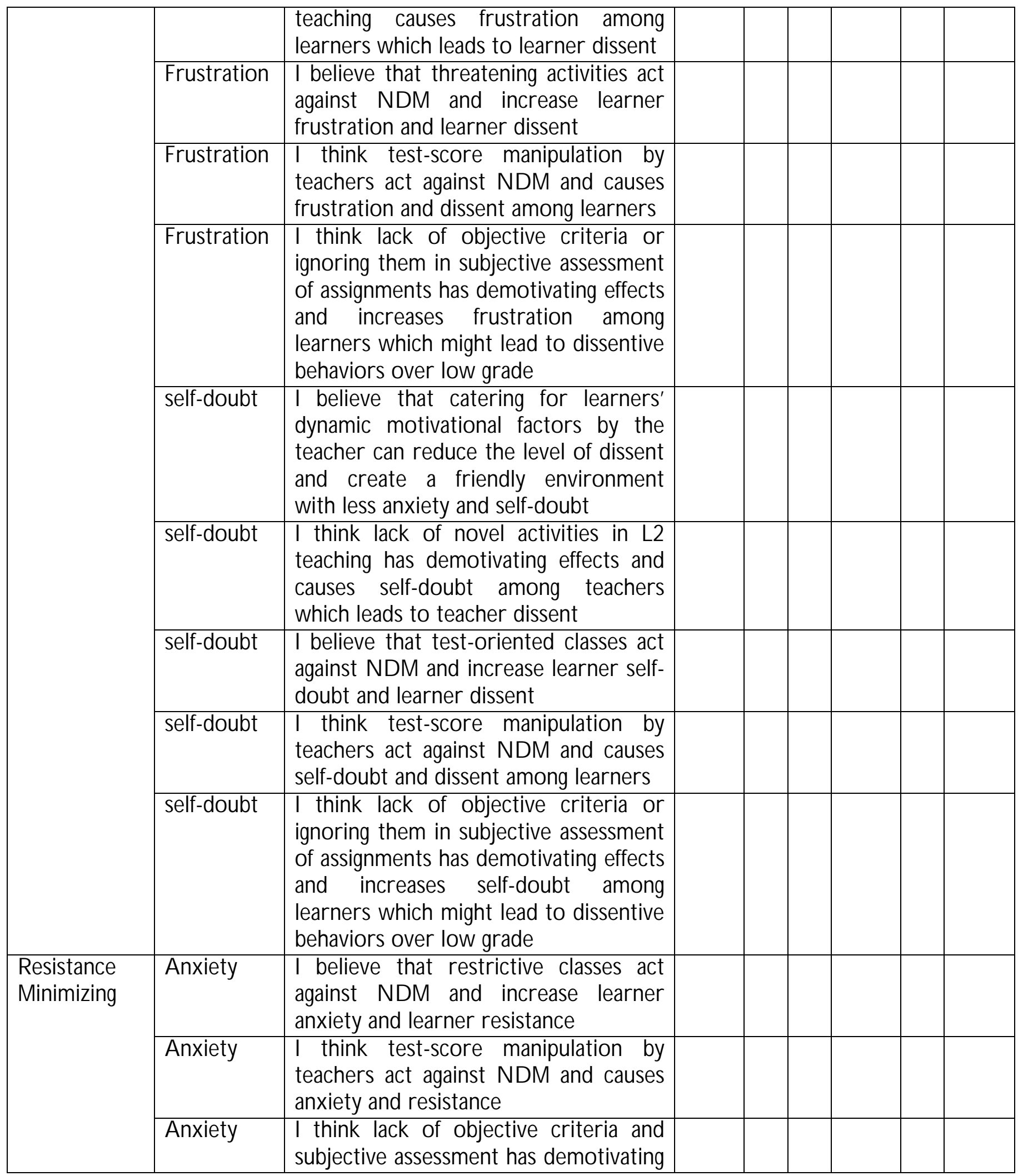




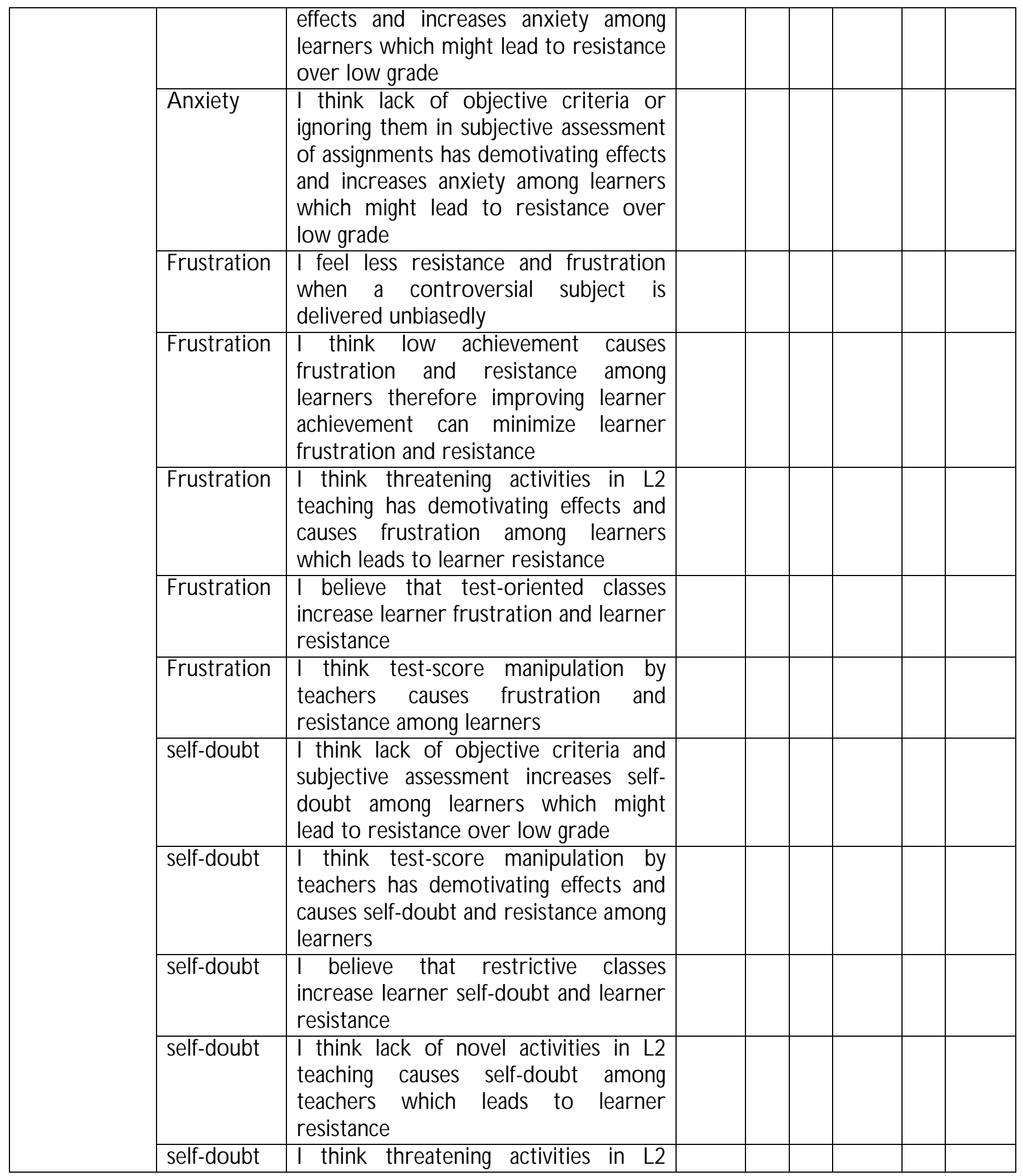




\begin{tabular}{|l|l|l|l|l|l|}
\hline & $\begin{array}{l}\text { teaching has demotivating effects and } \\
\text { causes self-doubt among teachers } \\
\text { which leads to teacher resistance }\end{array}$ & & & & \\
\hline
\end{tabular}

\section{Appendix B Semi-structured NDM-oriented Interview}

Table 5 Semi-structured N DM-oriented Interview

\begin{tabular}{|c|c|c|c|}
\hline Stages & Theme & Prompt & Coding responses \\
\hline Part 1 & $\begin{array}{l}\text { Experiences of } \\
\text { psychological } \\
\text { reactance in } 12 \\
\text { teaching-learning }\end{array}$ & $\begin{array}{l}\text { *What does 'psychological reactance in L2 } \\
\text { teaching-learning' mean to you? } \\
\text { *Have you experienced/witnessed } \\
\text { psychological reactance in terms of incivility, } \\
\text { resistance, and dissent? }\end{array}$ & $\begin{array}{l}\text { Elicited responses are } \\
\text { interpreted and coded } \\
\text { as } \\
1=\text { positive experience } \\
2=\text { negative experience } \\
3=\text { no experience }\end{array}$ \\
\hline \multirow[t]{3}{*}{ Part 2} & \multirow{3}{*}{$\begin{array}{l}\text { Explaining the } \\
\text { influence of meeting } \\
\text { motivational factors } \\
\text { at individual level to } \\
\text { manage psychological } \\
\text { reactance } \\
\text { with regard to } \\
\text { previous experiences }\end{array}$} & $\begin{array}{l}\text { *How influential is catering for individual } \\
\text { motivational factors during L2 teaching } \\
\text { learning by telling about your own } \\
\text { experiences? }\end{array}$ & $\begin{array}{l}\text { Elicited responses are } \\
\text { interpreted and coded } \\
\text { as } \\
1=\text { influential } \\
2=\text { uninfluential } \\
3=\text { undecided }\end{array}$ \\
\hline & & $\begin{array}{l}\text { * How influential is NDM when attended in } \\
\text { L2 teaching-learning context in your own } \\
\text { experience? }\end{array}$ & $\begin{array}{l}\text { Elicited responses are } \\
\text { interpreted and coded } \\
\text { as } \\
1=\text { influential } \\
2=\text { uninfluential } \\
3=\text { undecided }\end{array}$ \\
\hline & & $\begin{array}{l}\text { * How do you describe your experience of } \\
\text { managing oppositional behavior in a language } \\
\text { learning classroom where motivational } \\
\text { factors are encouraged to be expressed and } \\
\text { reinforced, instead of being put aside at the } \\
\text { cost of protecting rules and regulations }\end{array}$ & $\begin{array}{l}\text { Elicited responses are } \\
\text { interpreted and coded } \\
\text { as } \\
1=\text { positive experience } \\
2=\text { negative experience } \\
3=\text { no experience }\end{array}$ \\
\hline Part 3 & $\begin{array}{l}\text { Need for Reactance } \\
\text { management in } L 2 \\
\text { teaching-learning }\end{array}$ & $\begin{array}{l}\text { *How necessary is psychological reactance } \\
\text { management in } 12 \text { teaching-learning? }\end{array}$ & $\begin{array}{l}\text { Elicited responses are } \\
\text { interpreted and coded } \\
\text { as } \\
1=\text { necessary } \\
\text { 2=not necessary }\end{array}$ \\
\hline
\end{tabular}




\begin{tabular}{|c|c|c|c|}
\hline & & & 3=undecided \\
\hline & & $\begin{array}{l}\text { *Given your needs in classroom/online } L 2 \\
\text { teaching-learning what aspects of } \\
\text { psychological reactance management } \\
\text { (preventing incivility, minimizing resistance, } \\
\text { and managing dissent) can help you more? }\end{array}$ & $\begin{array}{l}\text { Elicited responses are } \\
\text { interpreted and coded } \\
\text { as } \\
1=\text { preventing incivility } \\
2=\text { minimizing } \\
\text { resistance } \\
3=\text { managing dissent }\end{array}$ \\
\hline Part 4 & $\begin{array}{l}\text { Strategies that can } \\
\text { facilitate reactance } \\
\text { management in L2 } \\
\text { teaching-learning }\end{array}$ & $\begin{array}{l}\text { *Do you think teacher-centered strateges } \\
\text { along with catering for L2 learners' NDM can } \\
\text { facilitate reactance management? How? }\end{array}$ & $\begin{array}{l}\text { Elicited responses are } \\
\text { interpreted and coded } \\
\text { as } \\
1=\text { Yes } \\
2=\text { No } \\
3=\text { Undecided }\end{array}$ \\
\hline & & $\begin{array}{l}\text { *Do you think that providing novel activities } \\
\text { can facilitate preventing incivility, minimizing } \\
\text { resistance, and managing dissent in face-to- } \\
\text { face/online } L 2 \text { teaching-learning? }\end{array}$ & $\begin{array}{l}\text { Elicited responses are } \\
\text { interpreted and coded } \\
\text { as } \\
1=\text { Yes } \\
2=\text { No } \\
3=\text { Undecided }\end{array}$ \\
\hline & & $\begin{array}{l}\text { *Do you think that improving learner } \\
\text { achievement can facilitate preventing } \\
\text { incivility, minimizing resistance, and managing } \\
\text { dissent in face-to-face/online L2 teaching- } \\
\text { learning? }\end{array}$ & $\begin{array}{l}\text { Elicited responses are } \\
\text { interpreted and coded } \\
\text { as } \\
1=\text { Yes } \\
2=\text { No } \\
3=\text { Undecided }\end{array}$ \\
\hline & & $\begin{array}{l}\text { *Do you think that eliminating test-oriented } \\
\text { classes can facilitate preventing incivility, } \\
\text { minimizing resistance, and managing dissent in } \\
\text { face-to-face/online L2 teaching-learning? }\end{array}$ & $\begin{array}{l}\text { Elicited responses are } \\
\text { interpreted and coded } \\
\text { as } \\
1=\text { Yes } \\
2=\text { No } \\
3=\text { Undecided }\end{array}$ \\
\hline Part 5 & & ir time. Do you have any questions that you & vould like to ask of me? \\
\hline
\end{tabular}

